\title{
Erratum: Structural diversity of supercoiled DNA
}

Rossitza N. Irobalieva, Jonathan M. Fogg, Daniel J. Catanese Jr, Thana Sutthibutpong, Muyuan Chen, Anna K. Barker, Steven J. Ludtke, Sarah A. Harris, Michael F. Schmid, Wah Chiu \& Lynn Zechiedrich

Nature Communications 6:8440 doi:10.1038/ncomms9440 (2015); Published 12 Oct 2015; Updated 29 Oct 2015

The original version of this Article contained an error in the spelling of the author Daniel J. Catanese Jr, which was incorrectly given as Daniel J. Catanese. This has now been corrected in both the PDF and HTML versions of the Article.

(c) (i)

This work is licensed under a Creative Commons Attribution 4.0 International License. The images or other third party material in this article are included in the article's Creative Commons license, unless indicated otherwise in the credit line; if the material is not included under the Creative Commons license, users will need to obtain permission from the license holder to reproduce the material. To view a copy of this license, visit http://creativecommons.org/licenses/by/4.0/ 